\title{
IMAGENS E NARRATIVAS ENTRECORTANDO A PRODUÇÃO DE CONHECIMENTOS ESCOLARES
}

\author{
Antonio Carlos Rodrigues de Amorim*
}

RESUMO: A estética rizomática deleuzeana de produção de conhecimentos potencializou a expressão do currículo compreendido como narrativa em acontecimentos e ao mesmo tempo celebração visual de um modo de ver e estar no mundo. O texto apresenta narrativas em corte que atravessam duas estruturas: a disciplina "fundamentos do ensino de ciências" para professoras de ensino fundamental e aulas de biologia de um professor da rede pública. O plano de composição, com imagem de clonagem de seres vivos, textos das alunas de pedagogia, intromissões minhas com citações de autores e a invenção da forma de sua apresentação, é a busca por criar outra escrita que não seja o aprisionamento e a morte das significaçōes, realizando registros que guardem mais aproximação com as experiências.

Palavras-chave: Imagens. Rizoma. Narrativa.

\section{CRISSCROSSING IMAGES AND NARRATIVES IN THE PRODUCTION OF SCHOOL KNOWLEDGE}

ABSTRACT: The Deleuzean rhizome aesthetics of knowledge production maximizes the expression of curriculum, understood both as a plot narrative and a visual celebration of our way of seeing the world and being in it. This paper presents mixed narratives in two structures: the discipline "Foundations of sciences teaching" for elementary/primary school teachers and biology classes given by a public school teacher. The composition plan, with images of the cloning of living creatures, texts written by pedagogy female students, my interventions quoting authors and the invention of its presentation format, is an attempt to create a different text that does not imprison or destroy meanings, and thus stays closer to real life experiences.

Keys words: Images. Rhizome. Narrative. * Doutor em Educação e professor da Faculdade de Educação da Unicamp. E-mail:
acamorim@unicamp.br

Educ. Soc., Campinas, vol. 25, n. 86, p. 37-56, abril 2004

Disponível em <http://www.cedes.unicamp.br> 
Imagens e narrativas entrecortando a produção de conhecimentos escolares

Figura 1

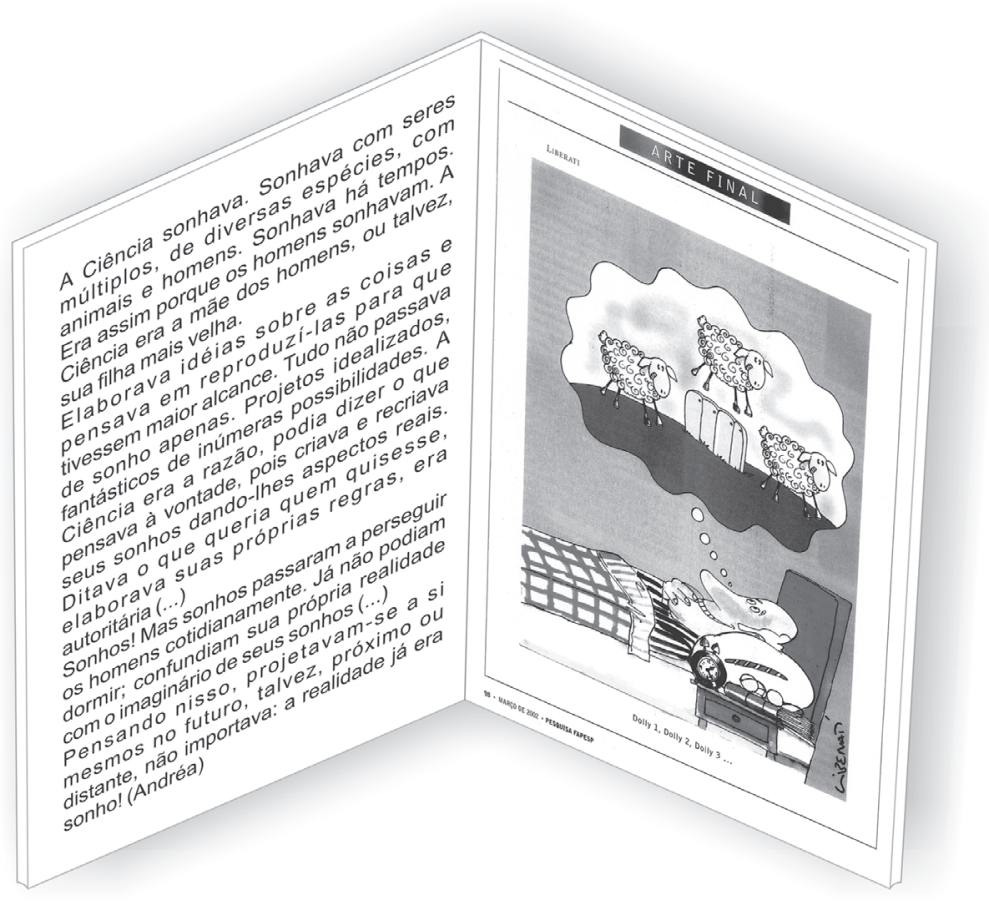

A gênese para Deleuze, segundo Jean-Luc Nancy (2000), parece ser, antes de tudo, um devir, que se move no meio das coisas, não em sua origem nem em seu fim. existência não-individuada e a um destino de vida indiferenciada, essa tentação de voltar a uma imortalidade indiferente - vemos o maior arrependimento do vivo com relação ao não-vivo. Este arrependimento nasce das profundezas de um passado remoto; sofremos por um estado há muito desaparecido, mas que será novamente possível por meio de nossas tecnologias, tornando-se no final das contas um objeto de nossa fascinação, de nossa nostalgia, de nosso desejo (Baudrillard, 2001).

Clones de subjetividade constituem padróes de identificação efêmeros. Para fazer girar este mercado, é necessário que novos tipos de clone sejam produzidos o tempo todo enquanto outros saem de linha, sejam obsoletos. (Rolnik, 2002)

Mas as coisas não param por aí. Notável orador lembra dos milhares de empregos criados pela comercialização do DNA, o crescimento econômico, o PIB, a balança... 
Antonio Carlos Rodrigues de Amorim

\section{Figura 2}

\section{Privatizemos o DNA
${ }_{\text {aterial genético, gatinhos clonados e dolizinhas infinitio }}$}

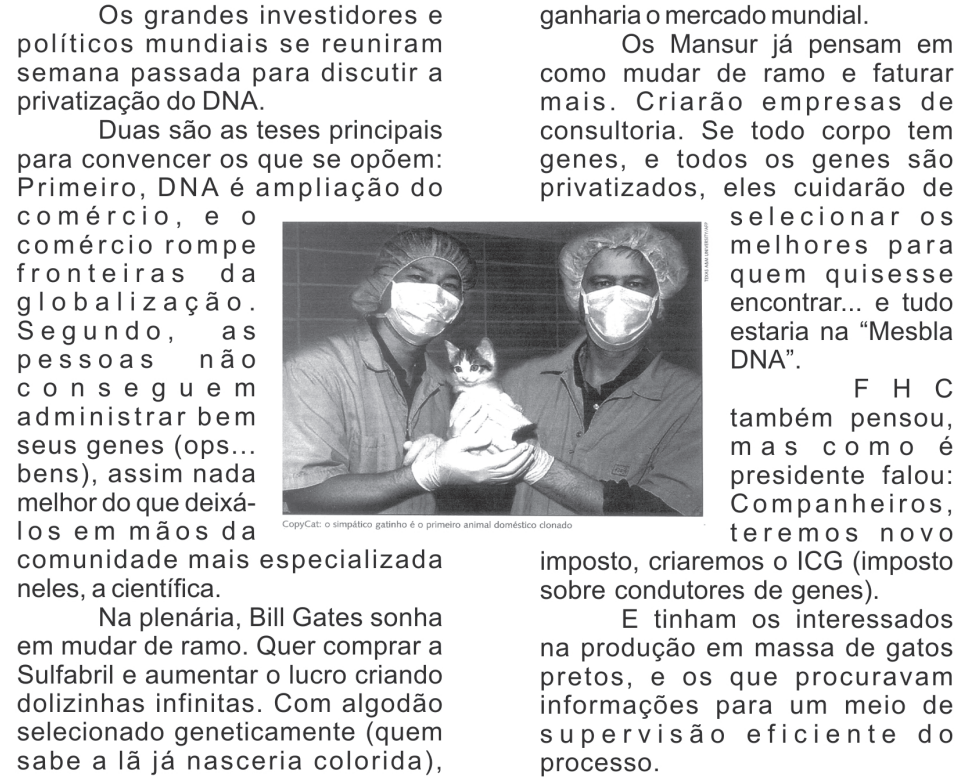

Enfim... Por quanto privatizaremos o material genético da humanidade?! Quem dá mais?!

Silêncio...

Silêncio...

Silêncio...

- Dou uma vida por ele! Diz alguém.

Silêncio...

- Próximo lance!!! (Leni)

Este texto, ao caminhar com alguns pensamentos de autores pós-estruturalistas, em particular Gilles Deleuze, tem uma textura de escrita aos pedaços, um patchwork no qual a biologia como objeto de ensino são as linhas que escolhi para organizar traçados que 
Imagens e narrativas entrecortando a produção de conhecimentos escolares

tiveram conexões com conceituação de outros autores, como Jean Baudrillard e Jacques Derrida.

Como plano de composição, em que imagens e escrita se mesclam, a estética rizomática deleuzeana de produção de conhecimentos potencializou a expressão do currículo compreendido como narrativa em acontecimentos e ao mesmo tempo celebração visual de um modo de ver e estar no mundo, lidando nos intervalos espaço-temporais, e pode trabalhar, à semelhança da fotografia pós-moderna, na desconstrução de processos em que a ideologia usa a fabricação de imagens para nos convidar a ocupar lugares fixos dentro de uma ordem social dominante. Segundo Linda Hutcheon (2002, p. 134), a fotografia pós-moderna usa e abusa das convenções verbais e visuais, apontando para as contradições e, desse modo, para os possíveis funcionamentos da ideologia.

Apostar na passagem entre as cenas, como no cinema. Porém, com a criação de uma escrita - próxima à experiência - em que a autoridade pedagógica das coisas, do objeto técnico seja "suspeitada" a partir da apresentação das suas possibilidades no atual e na cultura. Nessa linguagem, foca-se/desfoca-se o predicado e não o sujeito, por isso a atenção para o acontecimento, aquilo em que nos seres-coisas se processam significações. O acontecimento desdobra os seres-coisas, põe-nos em movimento, num fluxo de fragmentação, sem uma rede de conexões que ligam a um todo, a uma totalidade. São suas dimensóes em multiplicidades.

Mas pode um currículo acontecer? Ele sempre acontece, é um eterno retorno, é diferença. No seu livro Repetição e diferença, Deleuze afirma que os biólogos têm razão quando, colocando o problema da hereditariedade, não se contentam em atribuir-lhe duas funções distintas, que seriam como que a variação e a reprodução, mas querem mostrar a unidade profunda dessas funções ou seu condicionamento recíproco. É este o ponto em que as teorias de reprodução entram necessariamente numa filosofia de natureza. Quer dizer que a repetição nunca é repetição do "mesmo", mas sempre do diferente como tal, e que a diferença de si mesma tem como objeto a repetição (Gualandi, 2003, p. 78).

Planos de composição, desdobramentos do ser

Narrativas em cortes que atravessam estruturas foram compostas por professoras de $1^{\text {a }}$ a $4^{\text {a }}$ série em uma atividade dentro da disci- 
plina "fundamentos do ensino de ciências" no Programa Especial de Formação de Professores em Exercício, da Faculdade de Educação da UNICAMP, no primeiro semestre de 2002. Tendo os entremeios de três imagen $s^{2}$ como referência para a composição das narrativas, a produção de conhecimentos em aula, pelas professoras e por mim, encontraram expressão no plano de composição que foi apresentado no início deste artigo. Expressão em termos de constituição e de produção que, segundo Pierre Macherey (1991), em artigo que trata dos estudos de Deleuze sobre Espinoza, apresenta o conhecimento não como representação da coisa por intermédio de uma imagem mental, podendo ser ela mesma substituída por um conjunto de signos; mas ela é expressão, ou seja, produção e constituição da coisa. Ela se explica.

Um foco no ser-coisa, humano/não-humano, fluxo das produções na clonagem. Uma biologia que, em seu devir, territorializa e é espaço. A biologia é o lugar que ela espacializa.

O plano de composição, com imagens sobre clonagem dos seres vivos, textos das alunas, intromissões minhas com citações de autores e a invenção da forma de sua apresentação, é a busca por criar outra escritura (fotografia) que não seja aprisionamento e morte das significações, e nesse aspecto é muito inspirador o trabalho de Pat Palulis e Marulin Low (2001), com fortes referências no desconstrucionismo derrideano. Para Jacques Derrida (1995), em processos de escrita uma palavra sobrenomeia outra, que sobrenomeia outra e assim por diante, causando um apagamento do original (neste caso, a biologia exclusivamente como área científica, se é que isso algum dia existiu) e afastando cada vez mais a identificação de quem escreve daquilo que está escrito. Também se busca criar com esta outra escritura um campo em que a diferença só vai constituir-se na relação com outras diferenças e antecipando os sentidos sempre com relação ao sentido subseqüente.

Neste aspecto, os registros que guardam mais aproximação com as experiências e os acontecimentos têm suas potencialidades destacadas (Autrey \& Casemore, 2001) e essa é uma linha central sobre as quais giram e expandem outras perspectivas de compreensão da questão de pesquisa sobre produção de conhecimentos em aula. ${ }^{3}$

A contribuição dos escritos de Gilles Deleuze, para que eu possa produzir, por exemplo, a compreensão de currículo como 
Imagens e narrativas entrecortando a produção de conhecimentos escolares

acontecimentos, vai na direção de que seus constructos teóricometodológicos são inspiradores e carregam potencialidades de dar consistência às leituras interpretativas, fugindo de perspectivas que trabalham, também por exemplo, com a afirmação da indissociabilidade entre pesquisa e ensino, da coerência entre teorias e práticas no trabalho pedagógico, na reflexão como atos de consciência e tomada de decisão autônoma nos processos do trabalho pedagógico, na afirmativa do reconhecimento do professor como produtor de conhecimento pelas práticas de investigação, de pesquisa (acadêmica ou não) e pela intervenção mais acertada em seu trabalho. Situações essas que se aproximam de configuraçóes que nos remetem à unidade, ao homogêneo, à racionalidade, ao estabelecimento de uma ordenação da realidade que, quando reconhecida, pode ser transformada etc., as quais os princípios do rizoma colocam sob suspeita, não as apagando, mas potencializando-as como multiplicadoras, heterogêneas, irrepetíveis e caóticas.

A biologia emoldurada nos materiais didáticos ou quando o ser = corpo humano $=$ objeto técnico e cotidiano

"O livro não é a imagem do mundo segundo uma crença enraizada”. Esta afirmação de Gilles Deleuze e Félix Guattari (1995, p. 20) cria estranhamentos, ruídos, nos mapas resultantes de algumas análises dos papéis dos materiais didáticos como condicionantes da produção do conhecimento escolar. Incita a busca por fendas, aberturas nos muros que delimitam o espaço territorial traçado ao se considerar que existe uma aproximação bem forte entre o que está impresso no livro com as leituras que o professor faz e alunos fazem, o que significaria poder inferir quais aprendizagens acontecem.

Respaldando-me nos resultados de minha tese de doutorado, na qual trabalhei com duas professoras, uma de biologia e outra de ciências, e um professor de biologia que estavam há mais de dez anos em serviço, suponho que os conhecimentos científicos terão sua função, na configuração dos conhecimentos escolares, associada à sua utilidade na extensão de um território no qual se capturam conhecimentos pedagógicos, cotidianos e da experiência. 
Sua posição é submissa ao contexto da aula, às tradições das culturas escolares. Neste artigo, serão focados os movimentos que os currículos escolares, em sua produção na ação, fazem com os conhecimentos científicos da biologia. Ao recorrerem à reinvenção da tradição (por exemplo, usos dos materiais didáticos para leitura, realização de exercícios de aprendizagem e como síntese de conhecimentos), desterritorializam um processo de colonização dado pela centralidade dos conhecimentos científicos nas propostas curriculares oficiais na área de biologia.

Escolho pensar, o currículo como acontecimento, a partir da estética rizomática da produção do conhecimento escolar exige a captura de descontinuidades, de fraturas e de relaçóes não-lineares. Necessita, portanto, de lançar novos olhares para os inúmeros elementos exibidos sobre uma mesma superfície. Na superfície dos espaços escolares em que se encontram, os materiais didáticos podem ser dimensionados como um dos exemplos do processo pedagógico em que conteúdos e formas estão mutuamente envolvidos. É admirável e instigador o enquadramento dos materiais didáticos à cultura escolar em sua organização disciplinar, espaço-temporal (seleção de conteúdos, tempos úteis em aula, seqüência linear dos conteúdos, homogeneidade de temas) e de formação do professor e dos alunos. Essas características nascem dos ensinamentos de trabalhos que criticam a escola moderna, basicamente explicitando suas ações reprodutivistas e tecnicistas.

Os materiais didáticos presentes na escola também poderiam, então, ser percebidos como tipos de instrumentos cujas relações entre formas e conteúdos são necessárias à apropriação das diferentes linguagens sociais, incluindo as escolares. Sua existência é, portanto, uma das condições pressupostas para a produção do conhecimento escolar.

Escolhendo, dentro da unidade entre conteúdo e forma, a forma como o elemento preponderante para investigação como um dos determinantes da produção do conhecimento escolar, que tem como lócus privilegiado os momentos de ensino nos quais são trabalhados, pelos alunos e professores, os diferentes conteúdos das ciências, das artes, da literatura, Luciola Santos (1992, 1993, 1995) vem expondo, em seus trabalhos, algumas sugestóes provenientes de di- 
Imagens e narrativas entrecortando a produção de conhecimentos escolares

ferentes áreas que investigam as produções culturais do homem. Essa associação com os campos da produção artística e literária (e neles a existência de objetos, produzidos por várias técnicas, que se derivam em formas, que também são conteúdos) permite-me traçar e potencializar uma possível conexão com a questão ante a qual se depara Jean Baudrillard (2002) em seus estudos sobre um sistema de objetos.

A epopéia histórica do objeto técnico assinala as mudanças de estruturas sociais ligadas à evolução técnica, mas pouco diz sobre a questão de saber como os objetos são vividos, a que necessidades, além das funcionais, atendem, que estruturas mentais se misturam às estruturas funcionais e as contradizem, sobre que sistema cultural, infra ou transcultural, é fecunda a sua cotidianidade vivida. Não se trata dos objetos definidos segundo sua função ou segundo as classes em que se poderia subdividi-los para comodidade da análise, mas dos processos pelos quais as pessoas entram em relação com eles e da sistemática das condutas e das relaçóes humanas que disso resulta. (p. 10 e 11)

O alinhavar deste texto será continuado em linhas de fuga à perspectiva técnico-estruturante que os materiais didáticos têm. Convidado pelos dizeres de Jean Baudrillard (2002) e relembrando o trabalho de Antonio Batista (1996, p. 373), puxo deste último um fio: produto da ação de um conjunto de conquistadores, práticas, exercícios, o texto escolar é sempre o resultado da ação do docente que o lê, explora e apresenta aos alunos.

\section{Desenhos esquemáticos e textos em narrativas da ciência como objeto de ensino}

Todo o desenho será um jogo de fintas, de avanços, de recuos rápidos, até o momento em que o objeto se rende, em que a distância se reduz e o escultor esquece o modelo já apreendido definitivamente e dialoga rosto a rosto com a imagem possuída. (José Saramago, 1996, p. 176)

Lanço olhares para o trabalho do professor de biologia, estabelecendo como superfície tratável aquela que se expande pelos usos dos materiais didáticos. A fim de reunir o conjunto de co- 
nhecimentos científicos programados para serem postos à disposição dos alunos em cada série, o professor elaborou uma apostila e atualizava-a todos os anos, incluindo novas partes e retirando outras. Novos temas e questōes de vestibular mais recentes são o foco privilegiado nas modificações. A apostila foi norteadora das práticas em aula e recebeu uma atenção primorosa do professor, tanto graficamente, com textos claros e ricos em desenhos esquemáticos, quanto no lugar privilegiado que teve na organização dos trabalhos. Não existiam livros disponíveis para todos os alunos e um material de apoio, com o maior grau de completude possível, era considerado fundamental pelo professor. Quase todos os alunos tiraram cópia xerox da apostila e ela foi a matriz para as aulas: de onde foram retirados os esquemas, onde está descrita a teoria, onde estão propostos os exercícios. Foi ponto de apoio para a explicação do professor, mas que a ela não se prendeu para explicar os assuntos, pois priorizou uma narração que articulou desenhos e esquemas extraídos da apostila e apresentados na lousa, o sólido conhecimento teórico que tem e algumas poucas questôes que propôs à turma. $\mathrm{O}$ conjunto de $\operatorname{conceitos}^{4}$ cuja relação teceu em aula estava presente na apostila, que serviu também de referência para os alunos poderem estudar.

A idéia dessa apostila tem história! E parece-me que nessa história, além do caráter da falta de material didático para o ensino médio nas escolas, tem a característica de ser algo produzido pelo professor, com suas marcas, a estruturação que percebia, identificava na biologia. Disse o professor que, na elaboração da apostila, priorizou a correção conceitual e, como utilizou variados livros didáticos de ensino médio e superior para confeccioná-la, identificou contradições, equívocos e dúvidas, estas últimas mantidas na apostila e destacadas durante as aulas, numa tentativa de mostrar algumas incertezas aos alunos. Buscava na universidade e em testes de vestibular, instituiçôes valorizadas socialmente como produtoras de verdades, encontrar respostas para as dúvidas quanto aos conceitos contraditórios.

A apostila representava, também, com seus desenhos e texto em preto e branco um modelo para a interpretação biológica de fenômenos da realidade. $\mathrm{Na}$ apostila, o texto está separado dos esque- 
Imagens e narrativas entrecortando a produção de conhecimentos escolares

mas e desenhos, que ficam agrupados nas páginas finais dos blocos em que se reúnem os diferentes assuntos. Em momentos do texto, entre colchetes, estão indicadas as imagens conforme se associem a um ou outro tópico. Há locais na apostila em que o professor aponta para os leitores (alunos) outros tópicos que podem/devem ser lidos para melhor compreensão do assunto ali explicado; propõe aos alunos que revisem, releiam trechos já trabalhados em outras ocasióes da apostila da mesma série ou de séries passadas. São como palavras-chave com as quais os alunos poderiam abrir o hipertexto, no qual são garantidas possibilidades de conexões, não necessariamente as que o professor trabalhava nas aulas. A dimensão de um hipertexto também pode ser identificada com o conjunto de observaçóes que existem na apostila, destacadas no texto a partir de molduras que retêm funções dos órgãos, relações dos temas biológicos com o cotidiano genérico e aspectos mais relevantes selecionados pelo professor. Muitas das informaçôes emolduradas são retomadas nos exercícios, dispostos ao final da apresentação teórica de cada assunto. Relaçóes com aspectos sociais estão pouco presentes uma vez que, segundo o professor, eram trabalhados em duas outras disciplinas "saúde pública" e "meio ambiente" - igualmente sob sua responsabilidade em algumas séries, no ano em que realizei a pesquisa de campo.

A apostila, com seus esquemas e desenhos, propõe-se a uma ida do abstrato ao concreto, movimento análago que aproximo das discussões de Jean Baudrillard sobre os objetos técnicos.

"É na ida do abstrato ao concreto que o objeto técnico tende a atingir o estado de um sistema inteiramente coerente consigo mesmo, inteiramente unificado. Essa análise é essencial, pois nos fornece os elementos de uma coerência jamais vivida, jamais perceptível na prática (...). Neste nível, é possível considerar uma tecnologia estrutural que estude a organização concreta dos elementos técnicos simples em objetos técnicos mais complexos, sua sintaxe no seio de conjuntos técnicos simples - diferentes dos objetos reais assim como os sentidos entre os diversos objetos e conjuntos" (2002, p. 12).

Produzidos em outros campos culturais, por exemplo nos processos de editoração dos livros, inseridos na apostila e utilizados como matriz para a modelagem do conhecimento escolar em 
aula, os desenhos e esquemas são também multiplicidades. Somam-se à sua presença

- as lembranças do professor: Já desenhei muito, eu gostava muito de desenhar, mas no momento não... Eu gostava muito de pintar paisagens, fazer colagem, ia muito bem. ${ }^{5}$

- a aproximação escolar com a área artística: Eu gostava de aula de educação artística. Então eu fazia às vezes como distração, estudava, desenhava, pintava, isso mais na época da infância...

- e se conectam ao papel do aprendizado escolar de biologia a partir dos desenhos esquemáticos: desenhar. Eu gosto de fazer esquemas, eu aprendi pelo menos boa parte dos conteúdos através de esquemas. Geralmente quando eu leio um texto, vou tirando, vou fazendo um esqueminha com palavras-chave. Então, eu sempre peço para os alunos que copiem, desenhem o esquema da lousa, mesmo que tenham na apostila.

Esses tipos de lembranças, como ressalta Antonio Batista (1996, p. 359), podem ser tomados como indicadores do regime mais geral de possibilidades que os usos e as práticas (com os desenhos) significaram para sua formação, para a criação de uma familiaridade e para o estabelecimento de possíveis formas legítimas de apropriação dos conhecimentos científicos (faço as anotações através de um esquema, de um desenho). Significam formas de recontextualização, para fins didáticos, dos conhecimentos instrucionais.

Não sendo apenas formas de fixação dos conceitos biológicos, uma vez que os organizam, dão-lhes forma, movimento, os desenhos esquemáticos são leituras escolares da biologia. Em algumas aulas, exclusivamente era o professor quem os utilizava para explicar diferentes temas.

Serão apresentados trechos das aulas a respeito de sistema respiratório humano, em que os três seguintes esquemas foram usados em uma definida seqüência pelo professor. Primeiramente foi reproduzido, na lousa, um dos esquemas da apostila. Debruçado sobre ele, o professor teceu uma narrativa que procurou responder a questôes - do tipo $O$ que é respiração? Por que nós respiramos? - que buscaram recordar noções do processo de respiração celular que os alunos haviam estudado no ano anterior. 
Imagens e narrativas entrecortando a produção de conhecimentos escolares

(Figura 3)

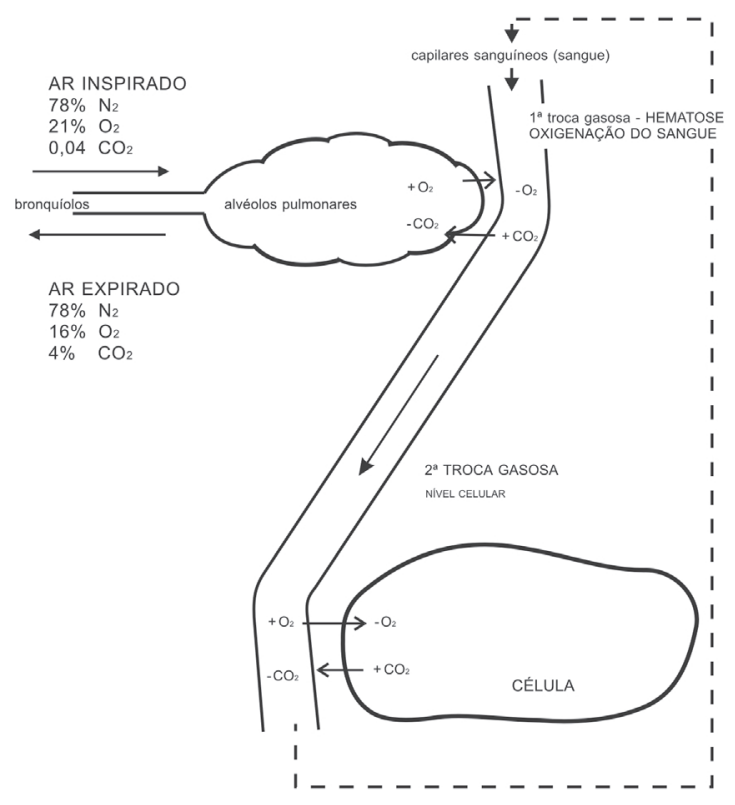

As trocas gasosas existem e foram explicadas contextualmente no esquema. No entanto, foi sobre os órgãos envolvidos nessa troca que praticamente se falou na aula. O professor afirmou isso. O sistema respiratório humano passou, então, às dimensões do desenho reproduzido abaixo: locais que possibilitam as trocas gasosas e a obtenção de energia pelas células. Ao mesmo tempo igual e diferente, posto que permite que respiremos (fato comum a todos os seres que têm vida) e que tem uma complexidade maior quando comparado com outros animais, o sistema respiratório humano (na forma de desenho esquemático) foi chamado a participar do contexto da aula na seguinte situação.

Quando o ar está saindo dos pulmôes e passa pela laringe, é produzido o som. As duas membranas, as cordas vocais onde o som é produzido, estão na laringe. $\mathrm{O}$ ar passa da laringe para a traquéia, final aqui do pescoço, um tubo cartilaginoso. Próximo aos pulmôes esse tubo se bifurca, se divide, formando duas ramificaçōes que penetram nos pulmōes: são os brônquios. Quem tem apostila, pessoal? Interessante sempre acompanhar, quando vocês estiverem estudando, um desenho, um esqueminha. Na página 20 vocês têm uma representação esquemática do sistema respiratório. Ao penetrar nos pulmôes, esses tubos estão se ramifican- 
do em tubinhos menores transformando-se em bronquíolos. No final de cada bronquíolo, uma dilatação como se fosse um saquinho, que chamamos de alvéolos pulmonares. (Aula do dia 3/9/1998 com o 20 B, destaques meus)

\section{(Figura 4)}

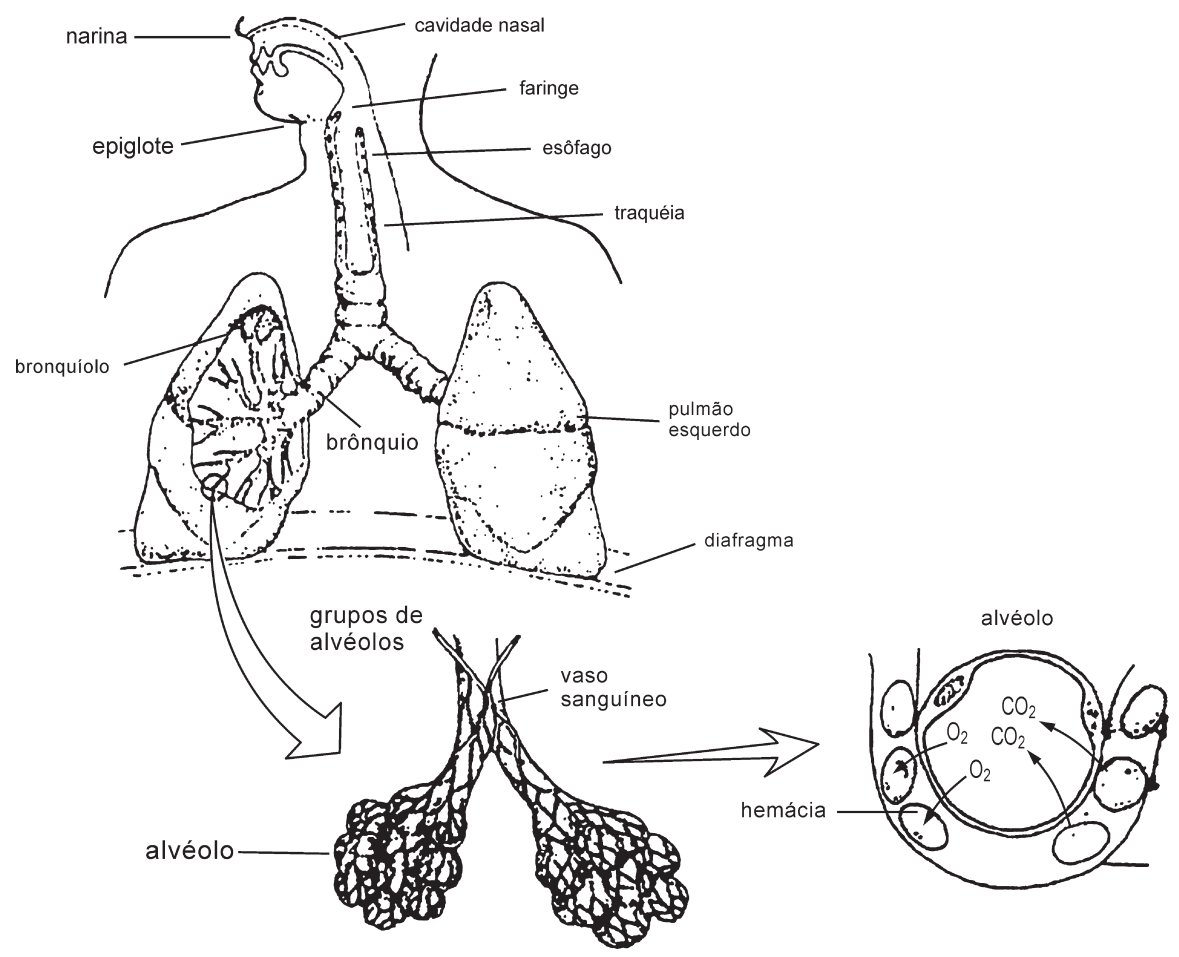

Uma parte do desenho estava ampliada: eram os alvéolos pulmonares, nos quais ocorrem as trocas gasosas que envolvem reações químicas. Após explicação detalhada, o primeiro esquema voltou novamente à cena. Nesse momento, entretanto, sobre o mesmo esquema o professor propôs situações à classe, das quais extraiu dados que exigiram explicações fornecidas na continuidade de sua narração.

Os alvéolos são todos envolvidos por vasos sangüíneos, capilares sangüíneos. $\mathrm{O}$ ar que penetra nesses alvéolos tem uma composição química, se for feita uma análise, com mais ou menos $78 \%$ de nitrogênio, $21 \%$ de oxigênio e menos de 1, 0,0304\%, de gás carbônico, entre outros gases que formam o ar. Já no ar que sai dos pulmões, que sai dos alvéolos, vamos encontrar uma composição de mais ou menos (aqui não altera), 78\% de nitrogênio, 16\% 
Imagens e narrativas entrecortando a produção de conhecimentos escolares

de oxigênio - olha, diminui bastante - e aumenta mais ou menos $4 \%$ de gás carbônico. Dá uma alteração daquilo que entra e daquilo que sai. Conclusão que poderia ser tirada aqui: alguma coisa acontece com o oxigênio do ar, uma vez nos alvéolos. Esse oxigênio vai ser usado, vai ser captado, alguma coisa vai acontecer, pois diminuiu a sua concentração. Já gás carbônico, tem alguma coisa no organismo que libera gás carbônico, pois aumentou a concentração desse gás carbônico. $\mathrm{O}$ que aconteceu aqui? Uma troca gasosa, uma troca mesmo: o organismo fica com oxigênio e libera o gás carbônico. Então, como que ocorreu isso? (Aula do dia 3/9/1998 com o 20 B)

O complicado - mas sobre isso é necessário falar um pouquinho -, que eram as reaçóes bioquímicas em nível dos alvéolos relativas às trocas gasosas (oxigênio e gás carbônico), abriu, na produção discursiva do professor, expansóes para que se entendesse o mecanismo envolvido na entrada e saída do ar dos alvéolos, ou seja, como se dá a inspiração, entrada de ar, e a expiração.

Há pessoas que vivem ou se deslocam em altas altitudes, acima de 3 mil metros de altitude, e possuem uma quantidade de hemoglobina no sangue muito maior do que pessoas que vivem em regiōes de altitudes menores. Inclusive atletas, quando se deslocam para locais onde a altitude é muito alta, vão algumas semanas antes para se adaptar. Então o indivíduo recém-chegado vai sentir tontura, fraquezas, vertigens, às vezes até vômitos, enfim, malestar geral justamente pela pouca quantidade de oxigênio que chega às células. Por quê? Porque quanto mais alto, quanto maior a altitude, o ar torna-se mais rarefeito e tem menor quantidade de oxigênio no ar. Além disso, tem aí uma diferença de pressão entre o meio externo e a pressão interna dos alvéolos. (Aula do dia 3/9/1998 com o $2^{\circ} \mathrm{B}$ )

Outro desenho da apostila foi a matriz que subsidiou a fala do professor a respeito da dinâmica de entrada e saída de ar nos pulmões. Das três figuras utilizadas é a que, na forma como foi desenhada, gera um certo movimento quando as duas imagens são comparadas, uma vez que existem diferenças no volume dos pulmões. Dinamizar esse desenho, buscando a compreensão dos fenômenos, foi o que fez o professor a partir de perguntas que relacionaram as diferenças entre as pressóes externa e interna ao corpo (puxando fios do exemplo que antecede o trabalho com o primeiro esquema) com a variação de volume da caixa torácica. Caminhou em campos que poderiam auxiliá-lo a explicar os fenômenos da inspiração e expiração e obter respostas dos alunos, que assistiram por vezes impressionados à complicada explicação que o pro- 
fessor se propôs a fazer e fez. Procurou nos conceitos físicos de pressão que porventura os alunos tivessem. Procurou em um exemplo hipotético de trocas gasosas entre os meios externo e interno à sala:

Se aumentar o volume, as moléculas ficarão mais espalhadas, mais distantes; vamos imaginar isso como uma sala de aula, nós aqui estamos sofrendo a pressão do ar daqui de dentro. Se aumentar a sala de aula, as paredes, teto, não tem nem um buraquinho, nada que permita a circulação do ar; o que acontece? A pressão vai ser maior ou menor sobre aquele menino que está dormindo e nem abriu o material? (Aula do dia 3/9/1998 com o $2^{\circ} \mathrm{B}$ )

\section{Figura 5}
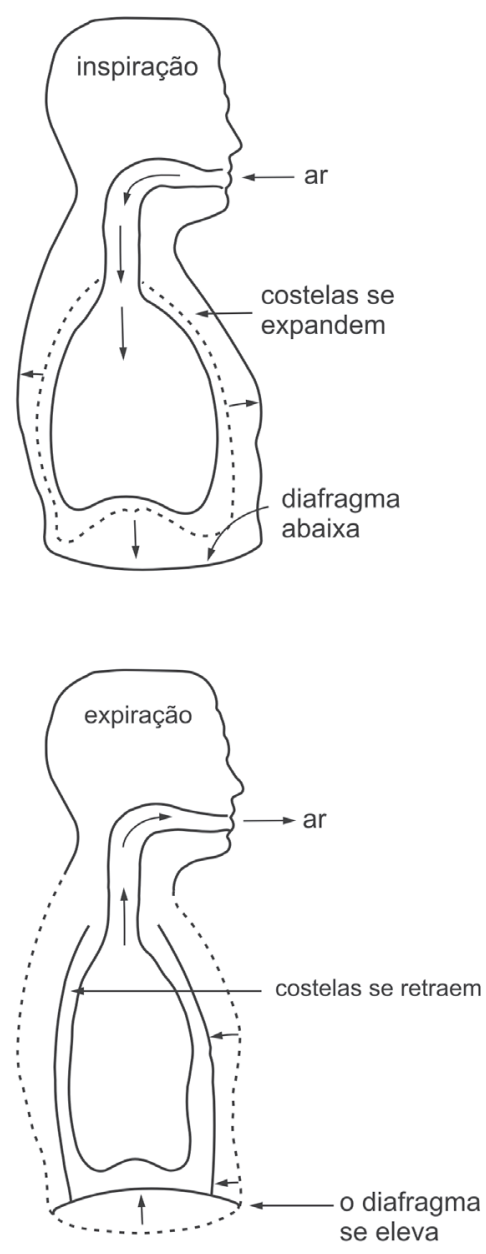

Educ. Soc., Campinas, vol. 25, n. 86, p. 37-56, abril 2004

Disponível em <http://www.cedes.unicamp.br> 
Imagens e narrativas entrecortando a produção de conhecimentos escolares

O professor de Biologia procurou continuar estimulando os alunos a pensarem a partir do modelo construído pelas imagens e pelo seu discurso:

Se você comparar com um outro caso: um aluno chegou atrasado, abriu a porta da sala; o que aconteceu? O ar vai entrar ou vai sair? Vai sair? Vai entrar? Pensa um pouquinho, ele vai entrar? Vai entrar; a pressão é maior, as moléculas de ar não estão mais unidas; por diferença de pressão, o ar vai entrar e ocorrer um equilíbrio. Isso daí é o que acontece similarmente nos alvéolos. (Aula do dia 3/9/1998 com o 20 B)

Segundo Jean Baudrillard (2002), cada um dos objetos práticos se associa a um ou vários elementos estruturais, mas em contrapartida escapam continuamente da estruturalidade técnica para as significações segundas, do sistema tecnológico dentro de um sistema cultural. $\mathrm{O}$ meio ambiente cotidiano permanece, em larga medida, um sistema "abstrato": nele os múltiplos objetos acham-se em geral isolados de sua função, é o homem que lhes assegura, na medida de suas necessidades, sua coexistência em um contexto funcional, sistema pouco econômico, pouco coerente, análogo à estrutura arcaica dos primitivos motores a gasolina: combinação de funções parciais, por vezes indiferentes ou antagônicas.

Os desenhos e esquemas eram em uma (des)estruturação resultados de diálogos do professor com os conhecimentos científicos; representavam formas de sua apresentação didática. Eram também um conjunto de peças, com as quais dialogava no seu discurso em aula, articulando-as na formação da biologia como objeto de ensino.

É possível, então, associarmos as imagens (desenhos e esquemas) a processos de gênese da biologia como objeto (técnico, prático e cotidiano) de ensino. Eugene W. Holland (1999) localiza nos primeiros anos da produção intelectual de Deleuze uma idéia de que a gênese é conferida menos pela tensão entre ser e não ser e mais na diferença e mudança. Nessa direção, a repetição (por exemplo, a volta às tradiçôes) deve requerer variação, diferenciação e improvisação. Essa relação entre repetição contínua e diferenciação produziria o mundo e não a produção de idênticos, similares, iguais, sob a égide de um regime de forças homogeneizante (Amorim, 2004, p. 158). Voltamos aqui à idéia do currículo como acontecimento. 
As imagens, na gênese da biologia como objeto de ensino, são sucessões de vários objetos, adicionados a outros, cumprindo sua função própria, mas transgredindo o conjunto, por vezes até cumprindo e transgredindo ao mesmo tempo a própria função.

O professor imprimiu aos desenhos e esquemas movimentos ao sabor dos conceitos científicos considerados necessários à compreensão dos fenômenos trabalhados (no caso, foi utilizado o exemplo da respiração humana) e que geravam a expectativa de produzir uma trama linear, que se desfazia e refazia ao sabor das comparações com situaçôes hipotéticas ou reais, cotidianas ou não, das retomadas de mesmos esquemas para finalidades distintas no processo de explicação, no desmonte de a perspectiva do desenho esquemático ser um decalque das explicações científicas de fenômenos naturais. É um desmantelar do decalque...

Os desenhos esquemáticos já eram participantes da produção do objeto de ensino "biologia", em seu caráter estruturante e técnico. Em práticas cotidianas de seu uso, em narrativas, foram introduzidos, mantidos e suprimidos outros pontos; processo de produção que ocorria sob condições que levam à permanência e transgressão de padrôes nas formas e nos conteúdos que entram na cultura escolar pelos veículos dos materiais didáticos.

Para dar conta do sistema cotidiano dos objetos, segundo Jean Baudrillard, "a análise estrutural é insuficiente (...) Focando-se a realidade psicológica e sociológica vivida dos objetos, que constitui, para além de sua materialidade sensível, um corpo de coerçôes, a coerência do sistema tecnológico (técnicas/tecnologias de ensino, neste caso) acha-se neles continuamente modificada e perturbada". É essa perturbação, e como se desenvolve a racionalidade dos objetos em luta com a irracionalidade das necessidades, e como tal contradição (ou antidialética) faz surgir um sistema de significações que se aplica em resolvê-las, que me interessaram neste texto.

Recebido e aprovado em fevereiro de 2004.

Notas

1. Nesta disciplina, trabalhei com referenciais dos Estudos Culturais da Ciência. Em particular, a atividade foi realizada após a leitura do livro Estudos Culturais da Ciência e Educa- 
Imagens e narrativas entrecortando a produção de conhecimentos escolares

ção, de Maria Lúcia Castagna Wortmann e Alfredo Veiga Neto, publicado em 2001, pela editora Autêntica.

2. Todas elas extraídas da revista Pesquisa FAFESP, do mês de março de 2002. Uma delas, que não aparece no início deste artigo, é a capa da revista na qual são apresentadas em linhas horizontais quatro repetidas cópias de uma mesma obra de arte mundialmente famosa. Ao todo são cinco diferentes artistas que foram eleitos para terem suas obras presentes na capa. Há uma alusão possível à idéia da reprodutibilidade da obra artística, e a manutenção de sua autenticidade e autoria, com a clonagem.

3. Que foi explorada na minha tese de doutorado denominada Os olhares do caminhante nos territórios do ensino de biologia, defendida em 2000, e que é atualizada no Projeto "O professor é autor?" - Interfaces entre Produção de Conhecimentos Escolares com a Formação de Professores de Biologia (Proc. FAep/Unicamp n. 1.372/2001), finalizado em 2003.

4. Para Deleuze, criar conceitos é construir uma região do plano, juntar uma região às precedentes, explorar uma nova região, preencher a falta. O conceito é um composto, um conglomerado de linhas, de curvas. Se os conceitos se devem renovar constantemente, é exatamente porque o plano de imanência se constrói por região, tem uma construção local, de proximidade em proximidade. É por isso que eles atuam por rompantes. Mas isso não quer dizer que não sejam objeto de retomadas e de sistematização. Pelo contrário, há aí uma repetição como potência do conceito: é a ligação de uma região à outra. E essa ligação é uma operação indispensável, perpétua, o mundo como uma manta de retalhos (Entrevista a Gilles Deleuze em Carlos Enrique Escobar, 1991).

5. Este trecho e os seguintes foram retirados da entrevista realizada com o professor de biologia no dia 2/10/1998.

\section{Referências bibliográficas}

AMORIM, A.C.R. Roteiros em ação: multiplicidades na produção de conhecimentos escolares. In: Lopes, A.C.; MACEDO, E. Curriculo de ciências em debate. Campinas: Papirus, 2004. p. 153192.

AUTREY, P.; CASEMORE, B. The Deleuzian tourist: a performance piece. Journal of Curriculum Theorizing, Rochester, v.17, p. 111-122, fall 2001.

BATISTA, A.A.G. Sobre o ensino de português e suas investigação: quatro estudos exploratórios. 1996. Tese (Doutorado) - Faculdade de Educação, Universidade Federal de Minas Gerais, Belo Horizonte.

BAUDRILLARD, J. A ilusão vital. Tradução Luciano Trigo. Rio de Janeiro: Civilização Brasileira, 2001. 
BAUDRILLARD, J. O sistema dos objetos. Tradução Zulmira Ribeiro Tavares. São Paulo: Perspectiva, 2002.

DELEUZE, G.; GUATTARI, F. Mil platôs: capitalismo e esquizofrenia. Rio de Janeiro: Editora 34, 1995. v. 1.

DERRIDA, J. Salvo o nome. Tradução Nícia Adam Bonatti. Campinas: Papirus, 1995.

ESCOBAR, C.H. Dossier Deleuze. Rio de Janeiro: Hólon, 1991.

GUALANDI, A. Deleuze. Tradução Danielle Ortiz Blanchard. São Paulo: Estação Liberdade, 2003.

HOLLAND, E.W. Marx and poststructuralist philosophies of difference. In: Buchanan, I. (Ed.). A Deleuzian Century? Durham; London: Duke University, 1999. p. 145-161.

HUTCHEON, L. The politics of postmodernism. London: Routledge, 2002.

MACHEREY, P. Pensar em Espinoza. In: Escobar, C.H. Dossier Deleuze. Rio de Janeiro: Hólon, 1991. p. 62-68.

PALULIS, P.; LOW, M.M. (W)rites of passage: disrupting circumscripitions through doublings of difference. Journal of Curriculum Theorizing, Rochester, v.17, p. 39-57, fall 2001.

ROLNIK, S. Despachos no museu: sabe-se lá o que vai acontecer... In: Rago, M.; Orlandi, L.B.L.; Veiga Neto, A. Imagens de Foucault e Deleuze. Rio de Janeiro: DP\&A, 2002. p. 309-324.

SANTOS, L.L.C.P. O discurso pedagógico: relação conteúdo-forma. Teoria e Educação, Porto Alegre, n. 5, p. 81-90, 1992.

SANTOS, L.L.C.P. Poder e conhecimento: a constituição do saber pedagógico. In: Oliveira, M.R.N.S. Didática: ruptura, compromisso e pesquisa. Campinas: Papirus, 1993. p. 131-141.

SANTOS, L.L.C.P. O processo de produção do conhecimento escolar e a didática. In: Moreira, A.F.B. (Org.). Conhecimento educacional e formação do professor. 2. ed. Campinas: Papirus, 1995. p. 27-37. 
Imagens e narrativas entrecortando a produção de conhecimentos escolares

SARAMAGO, J. A bagagem do viajante. São Paulo: Companhia das Letras, 1996.

WORTMANN, M.L.C.; VEIGA-NETO, A. Estudos culturais da ciência e educação. Belo Horizonte: Autêntica, 2001. 